\title{
Identification of Fusarium Species Causing Onion Basal Rot in Egypt and Their Virulence on seeds, Seedlings and Onion Bulbs
}

\author{
${ }^{1}$ Hala A. Mahdy, ${ }^{2}$ Nawal A. Eisa; ${ }^{1}$ Khalifa, M.M.A.; ${ }^{2}$ Khaled E. Eid, and ${ }^{2}$ Gamal A. Ahmed \\ ${ }^{1}$ Plant Pathology Res. Inst., Agric. Res. Center, Giza, Egypt. \\ ${ }^{2}$ Pl. Pathology Dept. Fac. Agric., Moshtohor, Benha Univ., Egypt. \\ Corresponding Auther: Hala A. Mahdy, Plant Pathology Res. Ins., Agric. Res. Center, Giza., Egypt \\ Corresponding author: Hala_abdou86@yahoo.com
}

\begin{abstract}
Fusarium oxysporum f. sp. cepae is the causal agent of onion basal rot disease. Onion basal rot disease caused by various Fusarium species is one of the economically important diseases of onion in Egypt. Identification of the prevalent pathogenic species causing onion basal rot disease is essential for designing management strategies, especially to develop resistant cultivars. Fourteen Fusarium isolates were obtained from onion bulbs collected from infected fields of of four different Governorates (Sharkia, Garbia, Behaira and Monofia) in Egypt. Inoculating onion bulbs (cv. Giza 20) with 14 of Fusarium isolates indicated that the fourteen tested isolates were pathogenic of onion. These isolates were identified as F. oxysporum, $F$. proliferatum and $F$. solani based on their morphological and molecular characteristics. As for virulence of each one of the isolates on bulbs and seedlings of onion, $F$. oxysporum caused severe basal rot and damping-off as a highly virulent species. F . proliferatum attacked onion bulbs while, $F$. solani caused pre- and post-emergence damping-off over $50 \%$.
\end{abstract}

Key words: Identification, Fusarium species, Onion basal rot, virulence, Egypt.

\section{Introduction}

Fusarium basal rot on onion is one of the destructive diseases attacking onion with damage rate more than $50 \%$ (Lacy \& Roberts 1982; Cramer 2000; Schwartz \& Mohan 2007; Dissanayake et al., 2009). Disease infection takes place in the field and symptoms such as delayed emergence, pre- and post-emergence damping-off, stunting, chlorotic leaves, necrosis, roots and bulb discoloration develop to rot and eventually death of the plant (Lager 2011). In addition, the quality and quantity losses of onion continue during storage (Brayford 1996; Lager 2011; Southwood 2012). This disease represents a great challenge in several countries beside Egypt. Among the various species of Fusarium being reported as the agent of onion basal rot in the world, $F$. oxysporum, $F$. solani and $F$. proliferatum are the most common isolated species, in which $F$. proliferatum has the ability of producing mycotoxins (Schwartz \& Mohan 2007; Stankovic et al. 2007; Zlata et al. 2008). F. oxysporum is one of the most destructive pathogens worldwide (Correll, 1991 and Schwartz \& Mohan, 1995). To manage the disease successfully, it is important to identify the pathogenic species of Fusarium (Del Mar Jiménez-Gasco \& Jiménez-Díaz, 2003 and Lievens et al. 2008). It is a common soil borne pathogen, which has an elevated level of host specificity with over 120 different formae specialis (f.sp.). F. oxysporum f.sp. cepae causes serious disease in onions with yield losses of more than $50 \%$ (Lacy \& Roberts, 1982). The pathogen is a Deuteromycete and has no known teleomorphic (sexual) stage (Brayford, 1996). F. oxysporum $\mathrm{f}$. $\mathrm{sp}$. cepae produces mycelium as well as three types of asexual spores: microconidia, macroconidia and chlamydospores (Cramer, 2000). Microconidia are the most commonly produced spores and are 5-12 $\mu \mathrm{m}$ in length. They are without septa and their shape varied from oval to kidney shaped. Macroconidia have a characteristic falcate shape, making them easily identifiable. In addition, they typically have three or four septa (Cramer, 2000; Agrios, 2005). Chlamydospores are produced in or on older mycelium, have one or two round cells and have thick cell walls, which defend the cells against degradation and antagonists. These spores help $F$. oxysporum f. sp. cepae to survive in soil, in the absence of its host, for a very long time, usually indefinitely. Fusarium species can survive either as mycelium or spores on plant debris in the soil (Agrios, 2005). In cold climate (winter months), it is necessary for Fusarium species to produce chlamydospores to survive during unfavorable periods. The fungus can disperse with soil particles and plant debris, which can be transported by both water and farm equipment (Cramer, 2000).

The initial symptoms of fusarium basal rot on leaves of seedlings are difficult to observe and plants could be killed before recognizing of any visual symptoms (Cramer, 2000). Symptoms on seedlings include delayed emergence, seedling damping-off and stunted growth. The symptoms above ground of mature bulbs are chlorosis and the curving of all leaves (Schwartz \& Mohan, 1995; Cramer, 2000). The chlorosis progresses to necrosis from the tip of the leaves and downwards, eventually killing the 
plant. The rot spreads from roots through the stem plate and up the storage leaves and may cause discoloration of the bulb outside. The affected tissue appears brown or reddish-brown and watery when the onion is cut in half. The stem plate is often the first part of the onion to show symptoms, usually as brown discoloration or occasionally white mycelium. When the entire stem plate is fully decayed, it can easily be separated from the rest of the bulbs. The roots typically rot, causing death of the plant. Some bulbs that are infected in the field may appear healthy and later develop rot in storage (Brayford, 1996). The fungus develops when the soil temperature is between 15 and $32^{\circ} \mathrm{C}$ (Schwartz \& Mohan, 1995; Cramer, 2000). Studies have shown that there is almost no disease when the soil temperature drops below $12^{\circ} \mathrm{C}$ and that the optimum temperature for the development of the fungus is between 25 and $32^{\circ} \mathrm{C}$.

Identification of plant pathogens in a culture based on micro- and macroscopic observations is the first and the most crucial step. However, this traditional method, especially for Fusarium species, is not always a responder due to the lack of expert mycologists, presence of closely related species and existing of different identification keys based on the morphological characteristics which can be variable depending on the culture environment (Mishra et al., 2003; Lager, 2011). Therefore, the use of speciesspecific primers that are designed based on DNA sequence polymorphism provides an accurate, reliable, reproducible and rapid identification of plant pathogens (Mulé et al., 2004 and Leslie \& Summerell, 2006). On the other hand, these molecular methods can identify the pathogens directly from plant tissues infected even by more than one Fusarium species or from fungal spores without the need for germination and are also sensitive to determine the minimum amount of fungal genomic DNA (Schweigkofler et al. , 2004).

This current study is aimed to identify Fusarium species as limiting agents of onion cultivation in several Governorates (Sharkia, Garbia, Behaira and Monofia) in Egypt using morphological as well as molecular methods, determining the virulence of pathogenic Fusarium isolates on onion seeds, bulbs and seedlings.

\section{2-Materials and Methods}

2.1. Sampling, isolation, purification and identification of fungal isolates:

Onion cv. Giza 20 plants were collected from four onions growing Governorates (Sharkia,Garbia,Behaira and Monofia) in Egypt during summer of growing seasons,2014, 2015 and 2016. Sampling was done randomly, as it extended the whole field. Samples were transferred to the lab in paper bags, then washed under running tap water. To remove the saprophytic fungi, the outer scales of the bulbs were detached. Infected tissues of roots, bulb scales, leaves and especially inner parts of the basal stem plate were cut, surface sterilized in $70 \%$ ethanol for $1 \mathrm{~min}$, rinsed twice in sterile distilled water (SDW), air dried on sterile filter papers and finally placed onto potato dextrose agar (PDA) medium amended with chloramphenicol. Cultures were incubated at $25^{\circ} \mathrm{C}$ for 6 days, and purification was done on $2 \%$ water agar (WA) medium using single-spore technique (Leslie \& Summerell 2006). All the monoconidial isolates were marked based on their region and the field of samples and stored in WA slants at $4^{\circ} \mathrm{C}$ for further use.

\subsection{Morphological characteristics}

The single-spore pure cultures of all isolates were sub-cultured on PDA medium to observe their morphological characteristics of macroconidia and microconidia. For other microscopic observations, such as the conidiophore length, presence of false heads or chains of microconidia on monophialides or polyphialides,micro slides of fungal culture were prepared in lactophenol-cotton blue, examined under microscope for their morphological characters and identified with the help of the standard keys provided (Leslie \& Summerell 2006). Eventually, to identify the Fusarium species illustrated keys and valid articles were used (Summerell et al. 2003; Leslie \& Summerell 2006). Microscopic photos were taken using a digital camera.

\subsection{Identification using IGS analysis: 2.3.1. DNA extraction}

For DNA isolation from the Fusarium isolates, $500-\mathrm{mL}$ flasks containing $200 \mathrm{~mL}$ of potato dextrose broth $(200 \mathrm{~g} / \mathrm{L})$ were inoculated with one fungal agar plug of each isolate and incubated at $27^{\circ} \mathrm{C}$ on a rotary shaker at $100 \mathrm{rpm}$ for 2 weeks. Then, mycelia and spores were sieved through 3 layers of cheesecloth, collected and stored at $-80^{\circ} \mathrm{C}$. The mycelium was subsequently ground in a $15-\mathrm{mL}$ plastic round- bottom tube, placed in liquid nitrogen, using a pre-cooled metal spatula and vortex. DNA was extracted from $20 \mathrm{mg}$ of the mycelium powder using the illustra DNA extraction kit (GE Health care, UK).

\subsubsection{IGS analysis:}

Fungal isolates which had culture and microscopic characteristics corresponding to Fusarium species were further characterized by analysis of the ribosomal intergenic spacer (IGS) regions as described by Edel $\boldsymbol{e t}$ al., (1995). IGS PCR fragments were amplified by PCR using the primers PNFo (5'- CCCGCCTGGCTGCGTCCGACTC -3'), and PN22 (5-CAAGCATATGACTACTACTGGC$3)$. Each isolate was assigned to an IGS type, defined by the specific restriction patters obtained with the two specific primers. The pairwise site differences between IGS types were represented as a dendrogram with the computer program using NTEdit and 
NTSYSpc Numerical Taxonomy System, Version 2.2 .

\subsection{Pathogenicity test on onion bulbs:}

Fourteen Fusarium isolates were screened for pathogenicity test based on the morphological and cultural characteristics. Onion bulbs of Giza20 cultivar, used for the pathogenicity test were brought from the stored yield of last year, and pathogenic isolates of fusarium basal rot was determined using the protocol of Toit et al. (2003). After removing the outer scales of onion bulbs as well as the roots and disinfecting with $70 \%$ ethanol, the basal stem was pierced with $2 \mathrm{~mm}$ diameter sterile cork borer to a depth of approximately $1 \mathrm{~mm}$. Finally, each hole was inoculated with $0.1 \mathrm{~mL}$ of conidial suspension having a concentration of $1 \times 10^{6}$ spores $/ \mathrm{mL}$ prepared by diluting 7-day-old Fusarium cultures in sterile distilled water (SDW). Control bulbs were inoculated only with SDW. After two weeks of incubation at room temperature $\left(25^{\circ} \mathrm{C}\right)$, bulbs were cut off from the inoculation sites and measured with a ruler for rot develops in the tissue. The test was conducted with two trials and three replicates for each isolate. The isolates were validated by re-isolating from intentionally inoculated onion bulbs with corresponding Fusarium isolates used for inoculation.

\subsection{Virulence of Fusarium isolates on seeds and} seedlings:

Virulence of pathogenic Fusarium isolates was assessed by pathogenicity tests on onion seeds.Virulence of Fusarium isolates under greenhouse conditions was determined by measuring percentages of pre- and post-emergence damping-off on onion seedlings. In this trail, 14 Fusarium isolates were chosen. Onion seeds cv. Giza 20 were washed under running tap water for 5 min disinfested with $70 \%$ ethanol and inoculated with each fungal isolate using the protocol of Bayraktar and Dolar ( 2011) which dipped for $20 \mathrm{~min}$ in spore suspension. Spore concentration was determined using a haematocytometer and adjusted to a final concentration of $5 \times 10^{5}$ spores $/ \mathrm{mL}$ by diluting in sterile distilled water, of each isolate immediately before sowing. Thirty seeds were inoculated for each isolate, sown equally into three pots, while the control seeds were inoculated with sterilized distilled water. Pots were filled with a sandy clay soil, which had been autoclaved twice and 10 seeds were sown in each pot. The pot experiment was conducted in randomized complete block design with three replications in the greenhouse with an average temperature of $26 \pm 1^{\circ} \mathrm{C}$. follows:

The damping-off disease assessment was as $\%$ Pre-emergence $=$

$\frac{\text { Number of non germinated seeds }}{\text { Number of sown seeds }}$ X 100

$\%$ Post-emergence $=$
$\frac{\text { Number of diseased and dead seedlings }}{\text { Number of germinated seeds }}$ X100

\section{Results}

\subsection{Fungal isolates}

Fourteen single-spore isolates of Fusarium spp. were obtained from collecting infected onion plants showing curved and yellow leaves, wilting, dampingoff and onions with sparse and sometimes reddish roots (Figure 1).

\subsection{Symptoms of onion basal rot in nature:}

The visual symptoms of onion basal rot caused by $F$. oxysporum f. sp. cepae can be observed on plant leaves, roots, basal stem plate, and bulb scales of small seedlings, mature plants, and dormant bulbs (Figure 1). The first signs of the disease appear on the leaf tips, which turn yellow and begin to die back as the plant nears maturity. Below ground roots rot is replaced by a mass of white mold growth. A noticeable symptom of the onion basal rot is the separation of roots from the bulb at the stem plate during uprooting (Figure1). 


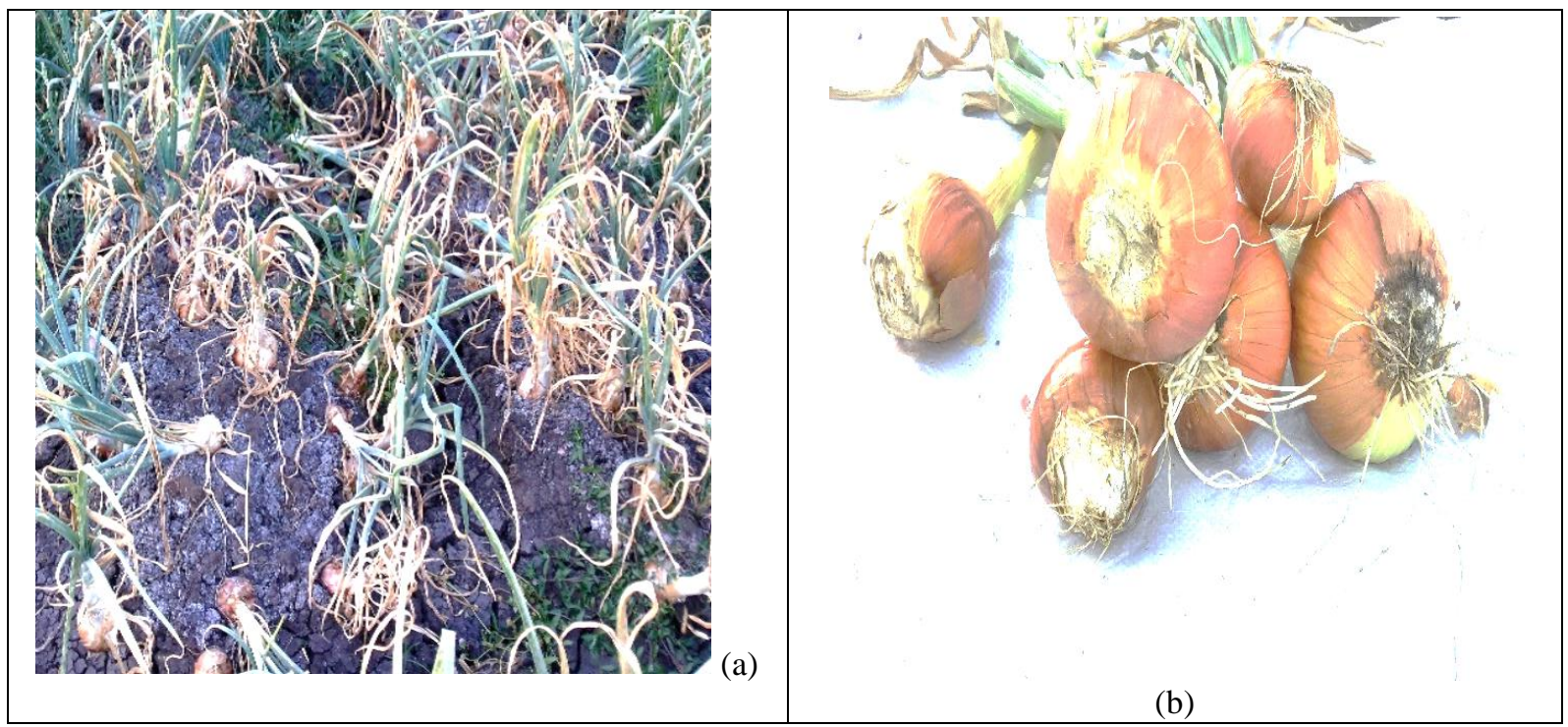

Figure 1. Symptoms of Fusarium basal rot of onion on leaves (a) and on the roots (b).

\subsection{Morphological identification}

Based on the investigated cultural and morphological characteristics as well as their comparisons with the identification keys, 14 pathogenic isolates were identified as $F$. oxysporum (ten isolates) and $F$. proliferatum (three isolates and F. solani( one isolate) (Table 1). The most distinct characteristics applied to the identification of each species were as follows (Fig 2):

$F$. oxysporum with white floccose mycelia. Some isolates produced dark violet pigment in the agar (this character was observed for most isolates).
Microconidia were formed in false heads on short monophialides. Thin-walled macroconidia were approximately straight and slightly tapered at the ends(Figure2,a,b,c).

$F$. proliferatum with abundant white aerial mycelia which discoloured to purple violet in centre, producing pale violet pigments in agar. Abundant microconidia were usually formed in short to moderate chains on mostly $\mathrm{V}$-shaped polyphialides and a few monophialides. Macroconidia were thin walled with distinct foot-shaped basal cell, tapered and slightly curved apical cell(Figure2,d,e,f).

Table 1. Macroscopic features of 14 Fusarium spp. infecting onions and representing different governorates in Egypt.

\begin{tabular}{lllllll}
\hline $\begin{array}{l}\text { Pathogenic } \\
\text { isolates code }\end{array}$ & $\begin{array}{l}\text { Geographical } \\
\text { origin (field) }\end{array}$ & Season & $\begin{array}{l}\text { Macroscopic features } \\
\text { upper side }\end{array}$ & $\begin{array}{l}\text { Macroscopic } \\
\text { features } \\
\text { underside }\end{array}$ & $\begin{array}{l}\text { Type of } \\
\text { Mycelium }\end{array}$ & Species \\
\hline 1g1 & Sharkia & 2014 & $\begin{array}{l}\text { Very white slightly } \\
\text { fluffy }\end{array}$ & Pale orange & Aerial & F. oxysporum \\
\hline $2 \mathrm{~g} 2$ & Sharkia & 2014 & $\begin{array}{l}\text { Very white slightly } \\
\text { fluffy }\end{array}$ & Pale orange & Aerial & F. oxysporum \\
\hline 3H & Sharkia & 2014 & White slightly fluffy & Pale orange & Aerial & F. oxysporum \\
\hline 4A1 & Sharkia & 2015 & White slightly fluffy & Pale orange & Aerial & F. oxysporum \\
\hline 5A2 & Sharkia & 2015 & White slightly fluffy & Pale orange & Aerial & F. proliferatum \\
\hline 6A3 & Sharkia & 2015 & White slightly fluffy & Pale orange & Aerial & F. proliferatum \\
\hline $7 \mathrm{C}$ & Sharkia & 2015 & White slightly fluffy & Pale orange & Aerial & F. proliferatum \\
\hline 8E1 & Garbia & 2015 & White slightly fluffy & Pale orange & Aerial & F. oxysporum \\
\hline 9E2 & Garbia & 2015 & White slightly fluffy & $\begin{array}{l}\text { Cream/ light } \\
\text { pink }\end{array}$ & Aerial & F. oxysporum \\
\hline $10 \mathrm{~F}$ & Garbia & 2015 & White slightly fluffy & Pale purple & Aerial & F. oxysporum \\
\hline $11 \mathrm{G} 1$ & Behaira & 2016 & $\begin{array}{l}\text { White pink slightly } \\
\text { fluffy }\end{array}$ & Pink & Aerial & F. solani \\
\hline $12 \mathrm{G} 2$ & Behaira & 2016 & White pink slightly & $\begin{array}{l}\text { Cream/light } \\
\text { fluffy }\end{array}$ & Aerial & F. oxysporum \\
\hline $13 \mathrm{G} 3$ & Behaira & 2016 & White slightly fluffy & Deep pink & Aerial & F. oxysporum \\
\hline $14 \mathrm{M} 2$ & Monofia & 2016 & White slightly fluffy & Pink & Aerial & F. oxysporum \\
\hline
\end{tabular}




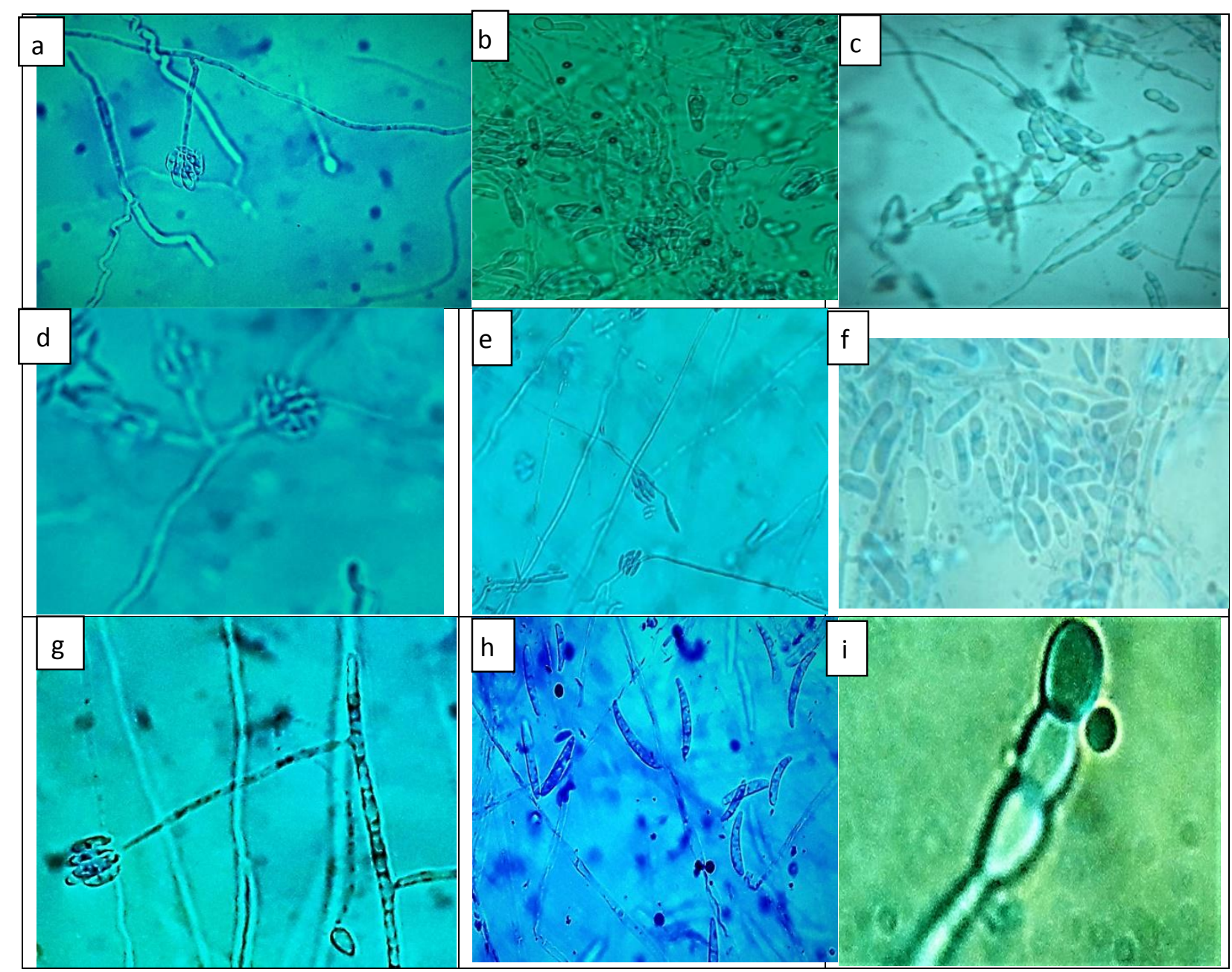

Figure2: Fusarium oxysporum. a, macro- and microconidia; c, terminal, intercalary chlamydospores and chlamydospores in chain(200x).F.proliferatum, chain of microconidia on short phialids (d)(200x), macroconidia(200x) and microconidia(400x) (e,f).F.solani,long phialid white false head (g)(200x),Macroconidia (h) (200x) and chain of chlamydospores (i)(400x).

\subsection{Identification using IGS analysis:}

The IGS region of the isolated fungal isolates was amplified using PNFo and PN22 as primers, since these two primers are considered specific for Fusarium oxysporum (Edel et al., 1995). The successful amplification of the IGS region indicates that not all isolates were belonging to Fusarium oxysporum species. The results revealed that among the 14 tested isolates, only 10 isolates $(1,2,3,4,8$, $9,10,12,13$ and 14) were genetically identical with Fusarium oxysporum species while no specific $F$. oxysporum IGS amplicons were detected with the other 4 isolates (Isolate No. 5,6,7, and 11). These results are confirmed successfully by the morphological and microscopically characterization of screened isolates. 


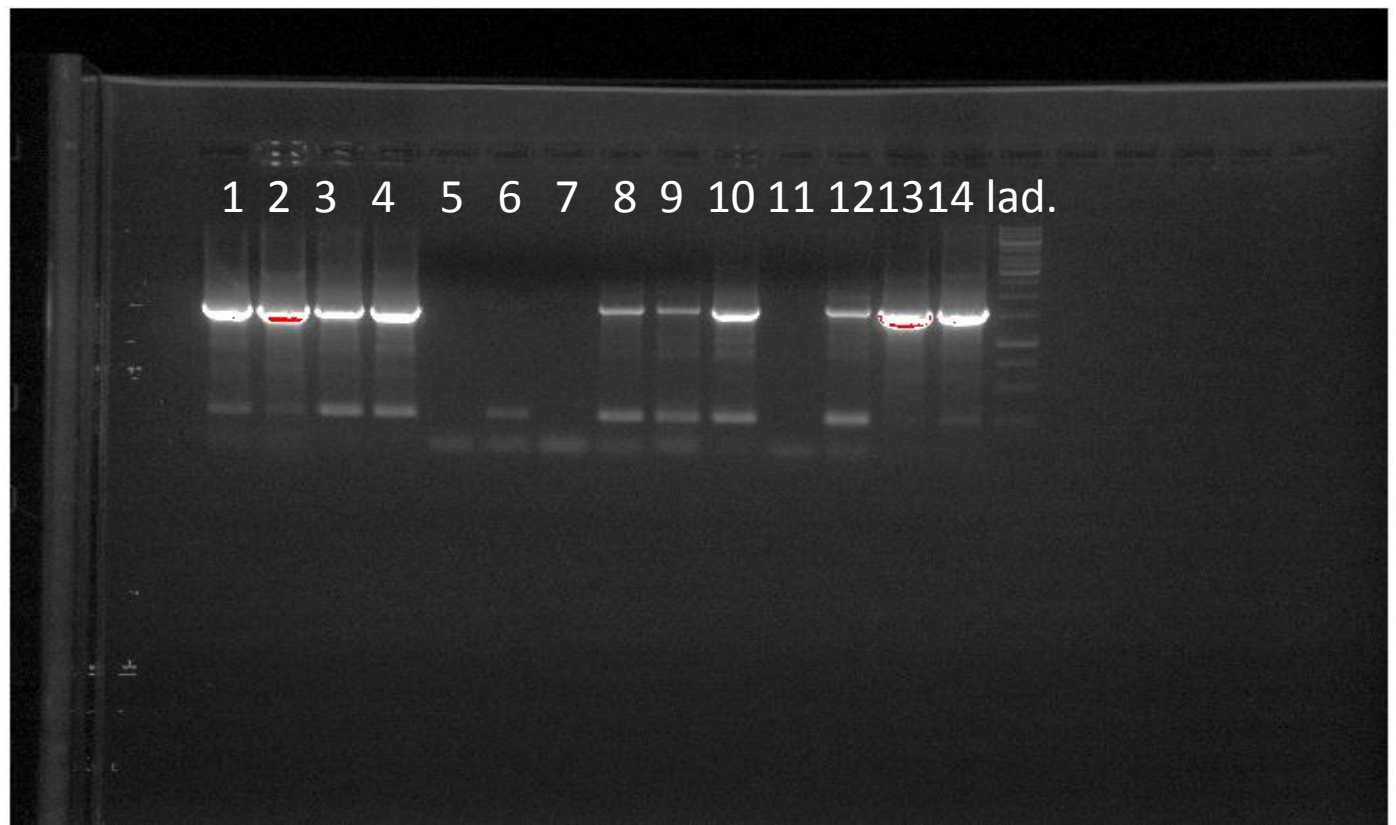

Figure 3: IGS region of 14 different isolated fungal isolates amplified using PNFo and PN22 specific primers.lad.250bp DNA ladder.

\subsection{Virulence of Fusarium isolates on onion} bulbs:

Virulence data of testing Fusarium isolates on onion bulbs as shown in Table 2. The 14 pathogenic isolates with different disease severities were classified into three groups: the first one is group A which included isolates $2 \mathrm{~g}_{2}, 9 \mathrm{E}_{2}, 4 \mathrm{~A}_{1}, 8 \mathrm{E}_{1}$ and $13 \mathrm{G} 3$ with average rot length of more than $3 \mathrm{~cm}$ as the most virulent isolates; the second one is group $\mathrm{B}$ which included isolates $12 \mathrm{G}_{2}, 3 \mathrm{H}, 1 \mathrm{~g}_{1}$ and $10 \mathrm{~F}$ with average rot length of $2-3 \mathrm{~cm}$ as moderately virulent and the third one is group $\mathrm{C}$ which included isolates $11 \mathrm{G}_{1}, 5 \mathrm{~A}_{2}, 6 \mathrm{~A}_{3}$ and $7 \mathrm{C}$ with average rot length less than $2 \mathrm{~cm}$ as less virulent group (Figure 4)

Table 2. Virulence of fourteen Fusarium isolates on onion bulbs as average rot length

\begin{tabular}{llll}
\hline \multicolumn{1}{c}{ Pathogenic isolates code } & Geographical region & Fusarium Species & Average rot length $(\mathrm{cm})$ \\
\hline $1 \mathrm{~g} 1$ & Sharkia & F. oxysporum & 2.63 \\
\hline $2 \mathrm{~g} 2$ & Sharkia & F. oxysporum & 3.94 \\
\hline 3H & Sharkia & F. oxysporum & 2.36 \\
\hline 4A1 & Sharkia & F. oxysporum & 3.71 \\
\hline $5 \mathrm{~A} 2$ & Sharkia & F. proliferatum & 1.90 \\
\hline 6A3 & Sharkia & F. proliferatum & 1.75 \\
\hline 7C & Sharkia & F. proliferatum & 1.96 \\
\hline 8E1 & Garbia & F. oxysporum & 3.37 \\
\hline 9E2 & Garbia & F. oxysporum & 3.90 \\
\hline $10 \mathrm{~F}$ & Garbia & F. oxysporum & 2.92 \\
\hline $11 \mathrm{G} 1$ & Behaira & F. solani & 1.75 \\
\hline $12 \mathrm{G} 2$ & Behaira & F. oxysporum & 2.05 \\
\hline $13 \mathrm{G} 3$ & Behaira & F. oxysporum & 3.08 \\
\hline $14 \mathrm{M} 2$ & Monofia & F. oxysporum & 2.76 \\
\hline SterilizedPDA disc (control) & & & 0.71 \\
\hline
\end{tabular}




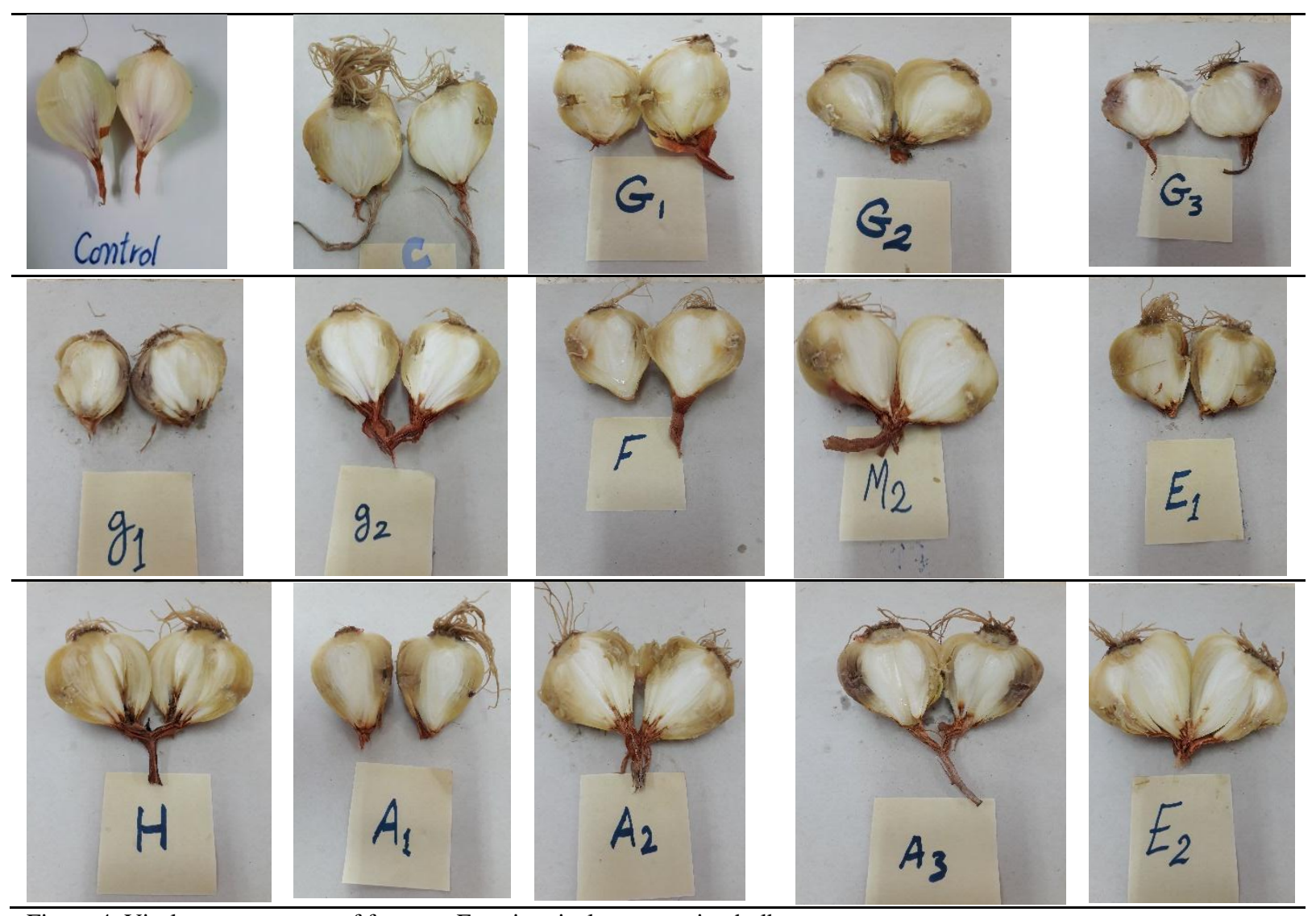

Figure 4. Virulence symptoms of fourteen Fusarium isolates on onion bulbs as rot symptoms $\mathrm{G} 2, \mathrm{G} 3, \mathrm{~g} 1, \mathrm{~g} 2, \mathrm{~F}, \mathrm{M} 2, \mathrm{E} 1, \mathrm{H}, \mathrm{A} 1, \mathrm{E} 2=F$.oxysporum $\mathrm{A} 2, \mathrm{~A} 3, \mathrm{C}=$ F.proliferatum $\mathrm{G} 1=$ F.solani

\subsection{Virulence of Fusarium isolates on onion seedlings:}

Data in Table 3 show that the tested Fusarium species not only cause post-emergence damping-off, but also pre-emergence damping-off, which calculated based on seedling emergence percentages.
Analyzing the effect of isolates on seed emergence determined that isolates $12 \mathrm{G}_{2} \quad(76.67 \%), \quad 5 \mathrm{~A}_{2}$ $(73.33 \%), 4 \mathrm{~A} 1(70 \%), 8 \mathrm{E}^{1}(66.67 \%), 1 \mathrm{~g}_{1}(63.33 \%), 7 \mathrm{C} \&$ $13 \mathrm{G}_{3} \quad \& \mathrm{M}_{2}(60 \%)$ and $11 \mathrm{G}_{1}(56.67 \%)$ caused preemergence damping off over $50 \%$. Therefore, they are the most destructive isolates.

Table 3. Comparing damping-off and disease severity of 14 Fusarium isolates based on their pathogenicity on onion seeds and seedlings.

\begin{tabular}{lccccc}
\hline \multirow{2}{*}{$\begin{array}{l}\text { Pathogenic isolates } \\
\text { code }\end{array}$} & $\begin{array}{c}\text { Geographical } \\
\text { region }\end{array}$ & \multicolumn{3}{c}{ \% Damping-off } & Virulence on seedlings \\
\cline { 3 - 5 } & & \%Pre & \%Post & \%Survival & \% Disease Severity \\
\cline { 3 - 5 } $1 \mathrm{~g} 1$ & Sharkia & 63.33 & 6.67 & 30.00 & 31.67 \\
\hline $2 \mathrm{~g} 2$ & Sharkia & 30.00 & 13.33 & 56.67 & 36.67 \\
\hline 3H & Sharkia & 16.67 & 10.00 & 66.67 & 15.00 \\
\hline 4A1 & Sharkia & 70.00 & 10.00 & 20.00 & 43.33 \\
\hline $5 \mathrm{~A} 2$ & Sharkia & 63.33 & 6.67 & 30.00 & 11.67 \\
\hline $6 \mathrm{~A} 3$ & Sharkia & 33.33 & 6.67 & 60.00 & 16.67 \\
\hline $7 \mathrm{C}$ & Sharkia & 60.00 & 3.33 & 36.67 & 10.00 \\
\hline $8 \mathrm{E} 1$ & Garbia & 66.67 & 13.33 & 23.33 & 21.67 \\
\hline 9E2 & Garbia & 43.33 & 13.33 & 43.33 & 26.67 \\
\hline $10 \mathrm{~F}$ & Garbia & 23.33 & 20.00 & 56.67 & 20.00 \\
\hline $11 \mathrm{G} 1$ & Behaira & 56.67 & 10.00 & 33.33 & 13.33 \\
\hline $12 \mathrm{G} 2$ & Behaira & 76.67 & 00.00 & 63.33 & 20.00 \\
\hline $13 \mathrm{G} 3$ & Behaira & 60.00 & $13 . .33$ & 26.67 & 21.67 \\
\hline $14 \mathrm{M} 2$ & Monofia & 60.00 & 6.67 & 33.33 & 20.00 \\
\hline Control & - & 00.00 & 00.00 & 100 & 0.00 \\
\hline
\end{tabular}


On the other hand, isolates $9 \mathrm{E}_{2}(43.33 \%), 6 \mathrm{~A}_{3}(33.33 \%), 2 \mathrm{~g} 2(30 \%), 10 \mathrm{~F}(23.33 \%)$ and $3 \mathrm{H}(16.67 \%)$ caused emergence damping -off less than $50 \%$. Also, the data in Table 3 illustrate that the highest disease severities were recorded with isolates $4 \mathrm{~A}_{1}, 2 \mathrm{~g}_{2}, 1 \mathrm{~g}_{1}$ and $9 \mathrm{E}_{2}$ which recorded $43.33,36.67,31.67$ and $26.67 \%$ respectively, while the other isolates recorded less than $20 \%$ disease severity.

\section{Discussion}

Basal rot of onion, mainly caused by various species of Fusarium, is widespread in most soils of onion plantations (Ashour et al. 1980; Kodama 1983; Entwistle, 1990). Also, most of the reports regarding basal rot have been done on yellow or white onion cultivars (Köycü \& Özer 1997; Bayraktar \& Dolar, 2011; Lager 2011; Southwood, 2012). In the current study, the aim is to identify Fusarium agents of onion which caused the basal rot and their virulence.

A total of 14 Fusarium isolates collected from onion plantations showing basal rot symptoms were identified into three species. Based on the morphological identification, the Fusarium species were identified as $F$. oxysporum (10 isolates), $F$. proliferatum (3 isolates) and $F$. solani (one isolate). Referring to the previous literature, $F$. oxysporum and $F$. proliferatum have been the most frequently isolated and the most common species associated with onion basal rot disease symptoms.

The current study identified Fusarium isolates which caused onion basal rot as mentioned above in the cultivated areas of four Egyptian governorates based on their morphological and molecular characteristics in addition to their virulence. $F$. oxysporum were the most destructive isolates of onion either on onion seedlings or bulbs. The obtained results are in harmony with those reported by Köycü \& Özer (1997); Schwartz \& Mohan, (2007); Stankovic et al. (2007); Dissanayake et al. (2009); Lager (2011); Carrieri et al. (2013) who isolated and tested the virulence of Fusarium species of different onion growing areas in the world.The species included; $F$. oxysporum, $F$. solani, $F$. proliferatum, $F$. acuminatum, $F$. culmorum, $F$. equiseti, $F$. subglutinans, $F$. tricinctum, $F$. redolens, $F$. graminearum, $F$. sambucinum, $F$. semitectum, $F$. avenaceum and $F$. verticillioides

Concerning the current results, $F$. oxysporum isolates were the most destructive pathogenic agents of onion where they caused severe damping-off and bulb rot. However, $F$. oxysporum- $4 \mathrm{~A}_{1}$ was the most virulent one on onion bulbs compared with $F$. proliferatum, meanwhile, it caused moderate virulence on onion seedlings. These results are in agreement with Schwartz \& Mohan (2007); Bayraktar, (2012) who reported that $F$. oxysporum is a major limiting factor of onion that can be a great threat to all growth stages of onion bulbs in farm and store conditions. However, despite F. oxysporum, the yield loss of $F$. proliferatum at store is more noticeable than on a farm (Southwood 2012). As past surveys, $F$. oxysporum had a wide spectrum of aggressiveness as we identified the isolates with high or less virulence and even avirulent ones (Özer et al. 2004; Schwartz \& Mohan, 2007; Galván et al. 2008). However, unlike also most reports regarding $F$. oxysporum as the a predominant isolated species, there are some reports which indicate other Fusarium species as predominant isolated ones (Stankovic et al., 2007; Zlata et al. 2008).

The molecular identification by amplification of the IGS regions using specific primers confirmed that 10 isolates of the obtained fungal isolates belonged to the species $F$. oxysporum. Further phylogenetic analysis of the IGS sequences suggested that there is a correlation between virulence and IGS sequences. It may be right to a certain extent that the sequence composition of the IGS reflects virulence. Comparable results were recorded with in vitro examination using morphological and microscopically investigative techniques. On the other hand, the results demonstrated that, 4 isolates were not belonging to $F$. oxysporum species. This was theoretically expected since slight changes in the sequence of the IGS region may reflect the genotype of the isolate (Weider et al., 2005). IGS regions contain various regulatory elements that govern the transcriptional efficiencies of the rRNA encoding genes. Differences in virulence and the accompanied plant defense responses may well require modifications in the regulation of the expression of rRNA encoding genes to maintain an optimal growth rate. It was reported that the rate of transcriptional production of pre rRNA was directly proportional to the number of enhancers located in the IGS (Cluster et al., 1987; Grimaldi and Di Nocera, 1988). Genotypes composed of longer IGS LVs may benefit from higher rDNA transcriptional rates via more enhancer and promoter sites in the subrepeat region of the IGS and thus exhibit faster development (i.e. higher growth rates). Allard et al. (1990) suggested that the selection acts directly on the sequence variability in the transcription units (i.e., sub repeats within the IGS). Zhang et al. (1990) determined that the high adaptability associated with a few specific alleles may result from adaptively favorable nucleotide sequences in either the transcription units or the IGS and that adaptability in barley depends more on the quality (i.e., sequence and length variation) rather than the quantity (i.e., $\mathrm{CN}$ ) of rDNA present. Nevertheless, molecular identification techniques for determining Fusarium oxysporum phenotyping and genotyping are still complicated due to the polyphyletic nature of many formae speciales, meaning that isolates belonging to different formae speciales may be more related than 
isolates belonging to the same formae specialis (Kistler, 1997; Lievens et al., 2008). JimenezGasco and Jimenez-Diaz (2003) demonstrated a correlation between the molecular identification of Fusarium oxysporum $\mathrm{f}$. sp. ciceris and its pathogenic races $0,1 \mathrm{~A}, 5$, and 6 based on specific primers and PCR assays. They were able by using specific SCAR primers and PCR assay to identify and differentiate isolates of $F$. oxysporum and assign the pathogenic races belonging to f. sp. ciceris. In this study, sequencing the IGS PCR fragments of 14 different $F$. oxysporum isolates proved a very useful tool in the way of discrimination of Fusarium oxysporum isolates. Further studies with virulence effector genes, secreted in xylem (SIX), and more varied virulent Fusarium isolate is highly recommended for confirming the current results of IGS primers and PCR assays.

\section{References}

Agrios, G.N. 2005. Plant pathology. Fifth edition. Elsevier Academic Press. London. UK. 922 pp.

Allard, R.W., Saghai-Maroof, M.A., Zhang, Q., Jorgensen, R.A. 1990. Genetic and molecular organization of ribosomal DNA (rDNA) variants in wild and cultivated barley. Genetics, 126: 74351.

Ashour, W., Elewa, I., Ali, A., Dabash, T. 1980. The role of some systemic and nonsystemic fungicides and fertilization on the enzyme activity and the control of Fusarium oxysporum f. sp. cepae, the cause of basal rot in onion. Agric Res Rev. 58:145161.

Bayraktar, H. 2012. Genetic diversity and population structure of Fusarium oxysporum f. sp. cepae, the causal agent of Fusarium basal plate rot on onion using RAPD markers. J Agric Sci. 16:139-149.

Bayraktar, H., Dolar, F.S. 2011. Molecular identification and genetic diversity of Fusarium species associated with onion fields in Turkey. $\mathrm{J}$ Phytopathol. 159:28-34.

Brayford, D. 1996. IMI descriptions of fungi and bacteria set 127. Mycopathologia. 133:35-63.

Carrieri R, Raimo F, Pentangelo A, Lahoz E. 2013. Fusarium proliferatum and Fusarium tricinctum as causal agents of pink rot of onion bulbs and the effect of soil solarization combined with compost amendment in controlling their infections in field. Crop Prot. 43:31-37.

Cluster, P. D., Marinkovic, D., Allard, R. W. \& Ayala, F. J. 1987. Correlations between development rates, enzyme activities, ribosomal DNA spacer-length phenotypes, and adaptation in Drosophila melanogaster. Proc. Natl Acad. Sci. USA 84, 610614.

Correll, J.C. 1991. The relationship between formae speciales, races, and vegetative compatibility groups in Fusarium oxysporum. Phytopathology, 81:10611064.

Cramer, C.S. 2000. Breeding and genetics of Fusarium basal rot resistance in onion. Euphytica. 115:159166.
Del Mar Jiménez-Gasco M, Jiménez-Díaz RM. 2003. Development of a specific polymerase chain reaction-based assay for the identification of Fusarium oxysporum f. sp. ciceris and its pathogenic races $0,1 \mathrm{~A}, 5$, and 6. Phytopathology. 93:200-209.

Dissanayake, M.L.M.C., Kashima,, R., Tanaka, S., S-i Ito. 2009. Genetic diversity and pathogenicity of Fusarium oxysporum isolated from wilted Welsh onion in Japan. J Gen Plant Pathol. 75:125-130.

Edel, V., Steinberg, C., Avelange, I., Laguerre, G., Alabouvette, C. 1995. Comparison of 3 molecular methods for the characterization of Fusarium oxysporum strains. Phytopathology, 85: 579585.

Entwistle, A.R. 1990. Root diseases. In: Rabinowitch HD, Brewster JL, editors. Onions and allied crops. Vol II. Boca Raton, FL: CRC Press; p. 103-154.

Galván GA, Koning-Boucoiran CFS, Koopman WJM, Burger-Meijer K, González PH, Waalwijk C, Kik C, Scholten OE. 2008. Genetic variation among Fusarium isolates from onion, and resistance to fusarium basal rot in related Allium species. Eur $\mathbf{J}$ Plant Pathol. 121:499-512.

Gao, X., Jackson, T., Lambert, K., Li, S., Hartman, G., Niblack, T. 2004. Detection and quantification of Fusarium solani f. sp. glycines in soybean roots with real-time quantitative polymerase chain reaction. Plant Dis. 88:1372-1380.

Grimaldi, G., Di Nocera P.P. 1988. Multiple repeated units in Drosophila melanogaster ribosomal DNA spacer stimulate rRNA precursor transcription. Proc Natl Acad. Sci. USA. 85: 5502-5506.

Jimenez-Gasco, M. M., Jimenez-Diaz, R. M. 2003. Development of a specific polymerase chain reaction-based assay for the identification of Fusarium oxysporum f. sp. ciceris and its pathogenic races $0,1 \mathrm{~A}, 5$ and 6 . Phytopathology, 93, 200-209.

Kistler, H.C. 1997. Genetic diversity in the plantpathogenic fungus Fusarium oxysporum. Phytopathology, 87: 474-479.

Kodama, F. 1983. Studies on basal rot of onion caused by Fusarium oxysporum f. sp. cepae and its control. Rep Hokkaido Prefect Agric Exp Stn., 39:1-65.

Köycü, N., Özer, N. 1997. Determination of seed-borne fungi in onion and their transmission to onion sets. Phytoparasitica., 25:25-31.

Lacy, M., Roberts, D. 1982. Yields of onion cultivars in Midwestern organic soils infested with Fusarium oxysporum f. sp. cepae and Pyrenochaeta terrestris. Plant Dis., 66:1003-1005.

Lager, S. 2011. Survey of Fusarium species on yellow onion (Allium cepa) on Öland [MSc dissertation]. Uppsala: Swedish (SLU), Swedish University of Agricultural Science.

Leslie, J.F., Summerell, B.A. 2006. The Fusarium laboratory manual. Oxford: Blackwell. UK. p.388.

Lievens, B., Rep, M., Thomma, B.P. 2008. Recent developments in the molecular discrimination of formae speciales of Fusarium oxysporum. Pest Manage Sci. 64:781-788.

Mishra, P.K., Fox, R.T.V., Culham, A. 2003. Development of a PCR-based assay for rapid and 
reliable identification of pathogenic Fusaria. FEMS Microbiol lett. 218:329-332.

Mulè, G., Susca, A., Stea, G., Moretti, A. 2004a. A species-specific PCR assay based on the calmodulin partial gene for identification of Fusarium verticillioides, $F$. proliferatum and $F$. subglutinans. Eur J Plant Pathol. 110:495-502.

Mulè, G., Susca, A., Stea, G., Moretti, A. 2004 b. Specific detection of the toxigenic species Fusarium proliferatum and $F$. oxysporum from asparagus plants using primers based on calmodulin gene sequences. FEMS Microbiol lett. 232:229-229.

Özer, N., Köycü, N.D. 2004. Seed-borne fungal diseases of onion and their control. In: Mukerji KG, editor. Disease management of fruits and vegetables: fruit and vegetable diseases. Dordrecht: Kluwer Academic; p. 281-306.

Özer, N., Köycü, N.D., Chilosi, G., Magro, P. 2004. Resistance to Fusarium basal rot of onion in greenhouse and field and associated expression of antifungal compounds. Phytoparasitica. 32:388-394.

Schwartz, H.F., \& Mohan, S.K. (1995). Compendium of onion and garlic diseases. The American Phytopathological Society. APS press. Minnesota. USA. 54 pp.

Schwartz, H.F., Mohan, S.K. 2007. Compendium of onion and garlic diseases and pests. 2nd ed. Minnesota: The American Phytopathological Society; $136 \mathrm{p}$.

Schweigkofler, W., O’Donnell. K., Garbelotto, M. 2004. Detection and quantification of airborne conidia of Fusarium circinatum, the causal agent of pine pitch canker, from two California sites by using a real-time PCR approach combined with a simple spore trapping method. Appl. Environ. Microbiol. 70:3512-3520.

Southwood, M.J. 2012. Evolution and detection of Fusarium oxysporum f. sp. cepae in onion in South Africa [PhD dissertation]. Stellenbosch: Stellenbosch University.

Stankovic, S., Levic, J., Petrovic, T., Logrieco, A., Moretti, A. 2007. Pathogenicity and mycotoxin production by Fusarium proliferatum isolated from onion and garlic in Serbia. Eur J Plant Pathol. 118:165-172.

Summerell, B.A., Salleh, B., Leslie, J.F. 2003. A utilitarian approach to Fusarium identification. Plant Dis. 87:117-128.

Toit, L.J., Inglis, D., Pelter, G. 2003. Fusarium proliferatum pathogenic on onion bulbs in Washington. Plant Dis. 87:750-750.

Weider, K.J., King, K.R., Thompson, D.M., Zia, C., Yarmush, M.L., Jayaraman, A.2005. Optimization of reporter cells for expression profiling in a microfluidic device. Biomed Microdevices. 7:213222.

Zhang, Q., Saghai Maroof, M.A., Allard, R.W. 1990. Effects of adaptedness of variations in ribosomal DNA copy number in populations of wild barley (Hordeum vulgare ssp. spontaneum). Proc. Natl. Acad. Sci. USA., 87: 8741- 8745.

Zlata, K.Š., Jelena, L., Stevan, M., Jelica, G.V, Mirjana, V., Svjetlana, A. 2008. Fusarium rot of onion and possible use of bioproduct. Zbornik Matice Srpske za Prirodne Nauke. 114:135-148.

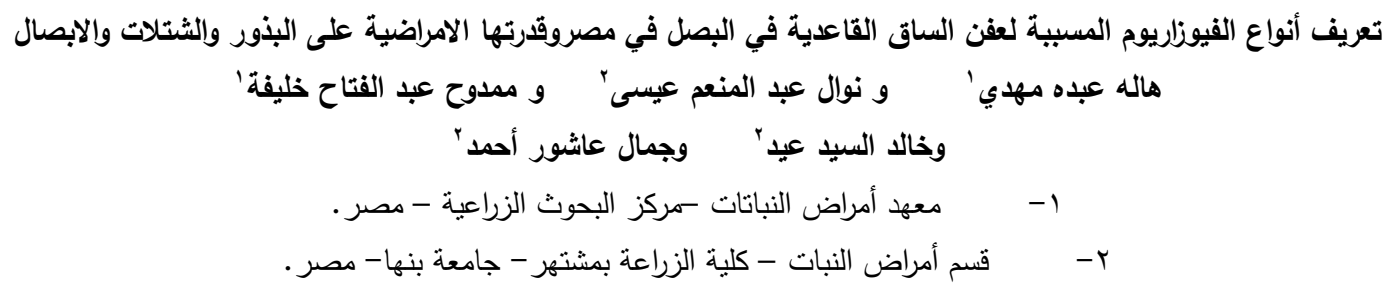

يعتبر الفطر Fusarium oxysporum f. sp. cepae مسبب مرض عفن الساق القاعدية في البصل من الأمراض الهامة في مصر ويعتبر تعريف الأنواع الممرضة والسائدة من الجنس فيوزاريوم ذات أهمية لوضع استراتيجيات المكافحة لهذا المرض ، وخداصة فئة إنتاج الأصناف المقاومة.

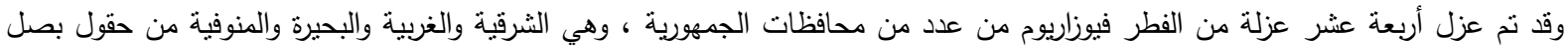

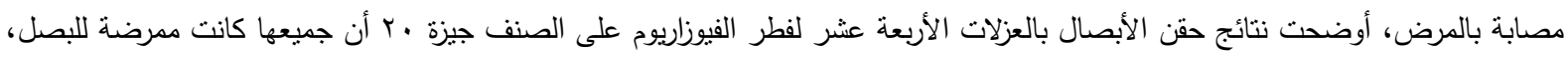
تم تعريف هذه العزلات على أنها تتبع ثلاثة أنواع من الفيوزاريوم وهي Fusarium oxysporum proliferatum \& (عشرعزلات)

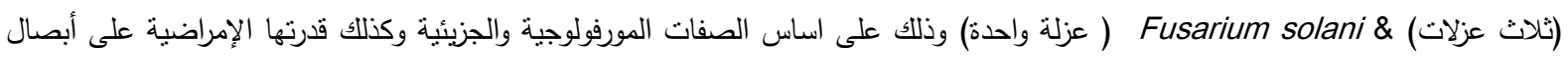
وشتلات وبذور البصل، وقد أظهرت النتائج ان الفطر Fusarium oxysporum أكثرهم شدة في إحداث المرض وموت البادرات ومن ناحية أخرى وجد أن الفطر Fusarium proliferatum يهاجم الأبصال بينما Fusarium solani يسبب أساسا موت البادرات قبل وبعد الانبات بما يزيد

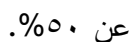

